\title{
Prostate endogenous calculi in a dog
}

\section{Cálculos prostáticos endógenos em um canino}

\section{João Marcelo Azevedo de Paula Antunes ${ }^{1}$, Larissa de Castro Demoner ${ }^{1}$, Luã Barbalho de Macedo $^{2}$, Heider Irinaldo Pereira Ferreira ${ }^{1}$, Ilanna Vanessa Pristo de Medeiros Oliveira ${ }^{2}$, Tardelli Candeia de Araújoº ${ }^{2}$, Camila Marinho de Miranda Oliveira $^{2}$, Muriel Magda Lustosa Pimentel ${ }^{3}$, Kilder Dantas Filgueira ${ }^{1^{*}}$}

\begin{abstract}
In dogs, prostatic calculi in most cases are asymptomatic and are diagnosed through routine imaging method being benign prostatic hyperplasia (BPH) is more frequent prostatic disease that affects dogs. The objective of this manuscript is to describes one case of endogenous prostatic calculi in a dog with BPH. A 18-year-old male non neutered mongrel dog with a 3-day history of decreased appetite, bloody feces and abdominal pain. Swelling occurred in rectal palpation of the prostate. Abdominal ultrasound visualized an increase of prostate and cavitations in its parenchyma. The animal died and at necropsy was viewed a bilateral and symmetrical increase of the prostate with cystic cavitation. During the section of the same, was visualized calculations were compounds by carbonate, phosphate, calcium, magnesium and ammonia, after analyzing physical chemistry. Histopathological prostatic tissue indicated BPH. Prostatic calculi in dogs are incidentally found on routine at veterinary clinics.
\end{abstract}

Key words: Benign prostatic hyperplasia, mineral concretions, cavitations

Resumo: Na espécie canina, os cálculos prostáticos, na maioria dos casos são assintomáticos e diagnosticados através de exames de imagem de rotina, sendo a hiperplasia prostática benigna (HPB) a doença prostática mais frequente que afeta os cães. O objetivo deste trabalho foi relatar um caso de cálculos prostáticos endógenos em 
um cão com HPB. Um canino, macho, 18 anos de idade, não castrado, possuía o histórico, há três dias, de diminuição do apetite, fezes com sangue e dor abdominal. Ocorria aumento de volume da próstata na palpação retal. O exame ultrassonográfico abdominal visualizou um acréscimo nas dimensões prostáticas e cavitação em seu respectivo parênquima. $\mathrm{O}$ animal veio a óbito e durante a necropsia foi visto um aumento bilateral e simétrico da próstata com cavitação cística. Durante a secção da mesma visualizou-se cálculos que eram compostos por carbonato, fosfato, cálcio, magnésio e amônia, após análise fisico-química. A histopatologia do tecido prostático indicou HPB. Os cálculos prostáticos em cães são achados incidentalmente na rotina da clínica veterinária.

Palavras chave: Hiperplasia prostática benigna, concreções minerais, cavitações.

\footnotetext{
${ }^{1}$ Veterinary Hospital, Rural Federal University of the Semi-Arid, Mossoró, Rio Grande do Norte, Brazil.

2 Self-employed Veterinarian, Natal, Rio Grande do Norte, Brazil. E-mail: luanb_macedo@hotmail.com

${ }^{3}$ Graduate Program in Animal Sciences, Rural Federal University of the Semi-Arid, Mossoró, Rio Grande do Norte, Brazil. E-mail: murielpimentel@yahoo.com.br

Corresponding author - * kilder@ufersa.edu.br

Submetido em 12.10.2014; Aceito em 15. 12. 2014
}

Introduction

Benign prostatic hyperplasia

$(\mathrm{BPH})$ is more common prostatic disease that affects dogs. Calculi in the prostate are associated to $\mathrm{BPH}$, inflammation and infection of the prostate (HURTES et al., 2013). Fifty percent of patients with prostatic calculi have BPH (FOX, 1962). The prostatic calculi are common in men/dogs of 
middle aged and older, however there are few reports in dogs (BORGES et al., 1997; BOKEMEYER et al., 2011; ZAMBELLI et al., 2012). In urology practices the prostatic calculi are found during the prostate transurethral resection due urethral obstruction. They have two origins: endogenous when has stasis and precipitation of inorganic elements (amylaceous bodies) present in prostatic secretion, and exogenous origin due the precipitation of urine constituents (KÖSEOGLU et al., 2010). The diagnosis is mainly through the radiology or ultrasound and the treatment is based on the therapy of the urological disease (HURTES et al., 2013). There are not many studies pertaining to prostatic calculi and their relationship to inflammation in the dog. The objective of this manuscript is to describes one case of endogenous prostatic calculi in a dog with BPH.

\section{Materials and Methods}

A 18-year-old male intact mongrel dog, weighing $9 \mathrm{~kg}$, was referred to the Veterinary Hospital of the Rural Federal University of the Semi-Arid (Mossoró, RN, Brazil). The patient had history of a 3-day history of decreased appetite, lethargy, bloody and soft feces, emesis, oligodipsia and oliguria. The patient underwent physical examination. The option was to request some additional tests which corresponded to complete blood count (CBC) with platelet count, serum chemistry (urea, creatinine, glutamic oxaloacetic transaminase and glutamic pyruvic transaminase) and abdominal ultrasonography. The dog died after 2 day due to an acute renal failure. The animal was sent for autopsy. Prostate tissue was collected for histopathology and the calculi were subjected to physicochemical analysis.

\section{Results and Discussion}

On physical examination, apathy, abdominal pain and palpably enlarged prostate were observed. A CBC showed 
lymphopenia $\left(4,000 / \mathrm{mm}^{3}, \quad\right.$ reference interval $[\mathrm{RI}] 12,000-30,000 \mathrm{~mm}^{3}$ ). A serum biochemical profile revealed increased of urea $(350 \mathrm{mg} / \mathrm{dl}$, RI $15-65$ $\mathrm{mg} / \mathrm{dl})$ and creatinine $(10.1 \mathrm{mg} / \mathrm{dl}, \mathrm{RI}$ 0,5-1,5 mg/dl). Glutamic oxaloacetic transaminase $(63 \mathrm{u} / \mathrm{L}, \mathrm{RI} 10-40 \mathrm{u} / \mathrm{L})$ and glutamic pyruvic transaminase $(50 \mathrm{u} / \mathrm{L}$, RI 10-40 u/L) revealed no significant changes.

Ultrasonography visualized an increase of prostate (length 5,2 $\mathrm{cm}$ [IR $2,4 \mathrm{~cm}, \pm 0.13 \mathrm{~cm}]$, height $3,9 \mathrm{~cm}[\mathrm{IR}$ $2,12, \pm 0,16 \mathrm{~cm}]$, width $3,8 \mathrm{~cm}$ [IR 2,59, $\pm 0.21 \mathrm{~cm}])$ and cavitations in its parenchyma with hyperechogenic calculi with an acoustic shadow formation. Necropsy confirmed a bilateral and symmetrical increase in size of the prostate gland (Figure 1). It was soft and white with neovascularization (or many anastomosing capillaries) on its surface and, on cut section, it contained areas of haemorrhage, congestion and cystic cavitations. The cystic areas contained red tinged fluid (red serous fluid would become serosanguineous). Inside of the cystic cavitations there was the presence of numerous mineral concretions/calculi (Figure 2). The calculi were formed by carbonate, phosphate, calcium, magnesium and ammonia; they had color ranging from white to yellow, irregular surface and hard consistency, ranging from $0.1 \mathrm{~mm}$ to $0.5 \mathrm{~mm}$. In the microscopy the prostatic tissue was irregular, dilated and acinar structures occupied by homogeneous proteinaceous substance were visualized. Such structures are bounded by columnar epithelial cells with round, small and uniform nuclei located in the basal pole of the cells. No cellular atypia or mitotic figures were seen. Observed severe inflammatory infiltrate composed of lymphocytes and plasmocytes with multifocal distribution. It was noted severe and diffuse tissue edema. Histopathological 
findings confirmed benign prostatic hyperplasia (BPH) (Figure 3). In the kidneys, ureters, bladder and urethra no calculations were visualized.

$\mathrm{BPH}$ is more common prostatic disease that affects older non-neutered dogs (BOKEMEYER et al., 2011; ZAMBELI et al., 2012). The close anatomic relationship between the prostate gland, urethra and urinary bladder is one reason for the high frequency of prostatic disease in humans (KODAKA et al., 2008; HWANG et al., 2010). BPH originates from aging and hormonal influence in dogs (BOKEMEYER et al., 2011; ZAMBELI et al., 2012) with the inflammation having important role in the formation of $\mathrm{BPH}$ and prostatic calculi in humans (HURTES et al., 2013). The cavitation in the prostate tissue from this case report had calculi and inflammation through histopathology. The most common clinical signs include dysuria, hematuria, tenesmus, dry feces and urinary infections (KÖSEOGLU et al., 2010; HURTES et al., 2013). In this report the 18 years old dog not had these clinical signs. The endogenous calculi are formed by the deposition of calcium salts on amylaceous bodies and are usually associated with prostatitis, $\mathrm{BPH}$, urethral lithiasis, urethral stenosis and urogenital tuberculosis (KODAKA et al., 2008; HWANG et al., 2010; HURTES et al., 2013), however, any disease process that can cause urinary calculi can also cause prostate calculi (HURTES et al., 2013). Surveys in humans have found that the calculi are mainly formed by a combination of calcium phosphate, calcium oxalate, carbonate apatite, sodium hydroxyurate, brushite and uric acid (KODAKA et al., 2008).

The composition of the calculi found in the prostatic cavitations of this dog was similar to calculi found in the prostatic calculi in humans (HWANG et 
al., 2010). Having regard to the mechanism of formation of endogenous calculation, and the prostatic inflammation is a common observation in prostate calculi; begin to notice a greater importance in the pathophysiology of $\mathrm{BPH}$ in prostatic calculi formation (HWANG et al., 2010). Still do not know the clinical significance of prostatic calculi in humans and dogs (HWANG et al., 2010), however large calculi are associated with urinary retention, prostatitis and pelvic pain syndrome (KODAKA et al., 2008). Prostatic calculi in human beings are not associated to risk of develop cancer (HWANG et al., 2010), and the clinical signs shown by the dog in this case report are related to acute renal failure and not to enlarged prostate and prostatic calculi.

\section{Conclusion}

Prostatic calculi in dogs seem similar to those in humans and may being diagnosed incidentally on routine at veterinary clinics what generates the need to be perform studies between inflammation and prostatic calculi.

\section{References}

BOKEMEYER， J.; PEPPLER， C.; THIEL, C.; FAILING, K.; KRAMER, M.; GERWING, M. Prostatic cavitary lesions containing urine in dogs. Journal of Small Animal Practice, v.52, n.3, p.132-138, 2011.

BORGES, A.S.; MENDES, L.C.N.; VASCONCELOS, R.; ALVES, A.L.G.; RODRIGUES, C.A. Prostatic calculus in a dog. Brazilian Journal of Veterinary and Animal Science, v.49, n.6, p.693-699, 1997.

FOX, M. Treatment of prostatic calculi. British Journal of Urology, v.34, n.1, p.93-98, 1962.

HURTES, X.; DAUDON, M.; MERIA, P. Cálculos prostáticos. EMC-Urología, v.45, n.3, p.1-7, 2013.

HWANG, E.C.; CHOI, H.S.; IM, C.M.; JUNG, S.I;. KIM, S.O.; KANG, T.W.; 
KWON, D.D.; PARK, K.S.; RYU, S.B.

Prostate calculi in cancer and BPH in a

cohort of Korean men: Presence of

calculi did not correlate with cancer

risk. Asian Journal of Andrology,

v.12, n.2, p.215-220, 2010.

KODAKA， T.; HIRAYAMA， A.;

SANO, T.; DEBARI, K.; MAYAHARA,

M;. NAKAMURA, M. Fine structure

and mineral components of primary

calculi in some human prostates.

Journal of electron microscopy, v.57,

n.4, p.133-141, 2008.
KÖSEOGLU, H.; ASLAN, G.; SEM, B.H.; TUNA, B.; YÖRÜKOGLU，K. Litiasis prostática: cálculos silentes. Actas Urológicas Espñolas, v.34, n.6, p.555-559, 2010.

ZAMBELLI, D.; CUNTO, M.; GENTILINI, F. Validation of a model to develop a symptom index for benign prostatic hyperplasia in dogs. Reproduction in Domestic Animals, v.6, suppl.6, p.229-231, 2012. 


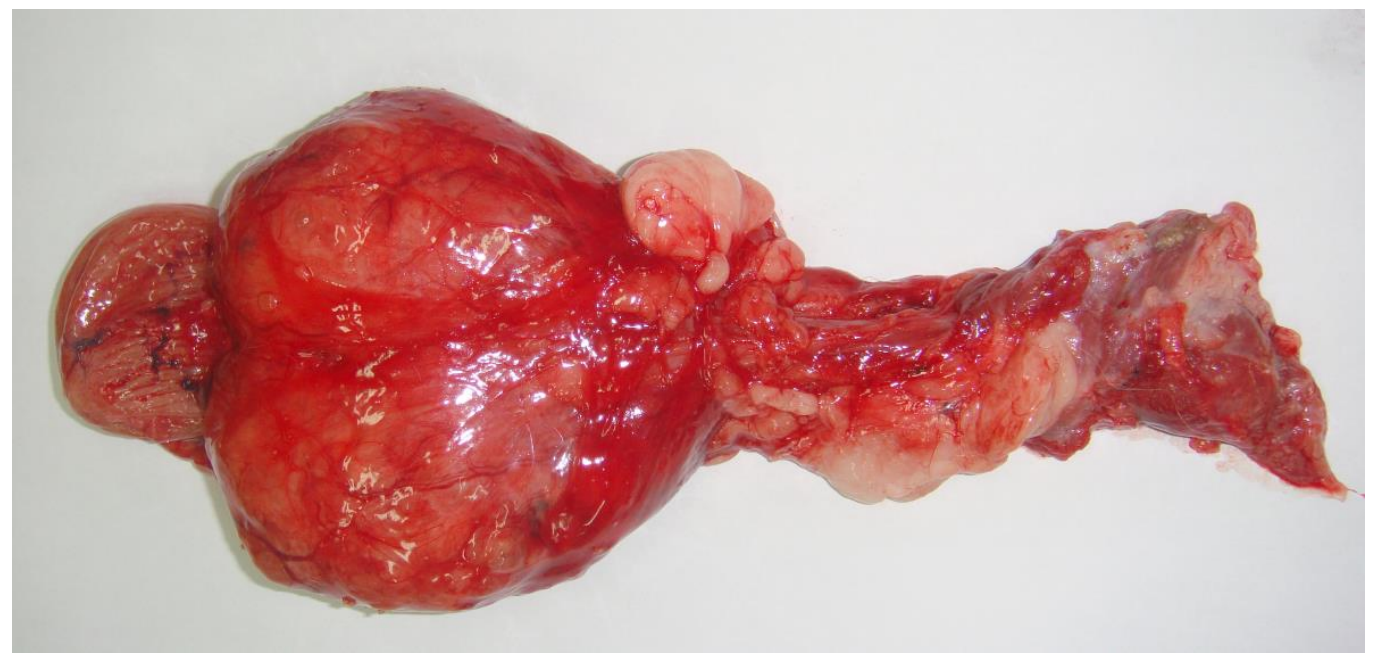

Figure 1. Prostate at macroscopy with enlarged lobes.

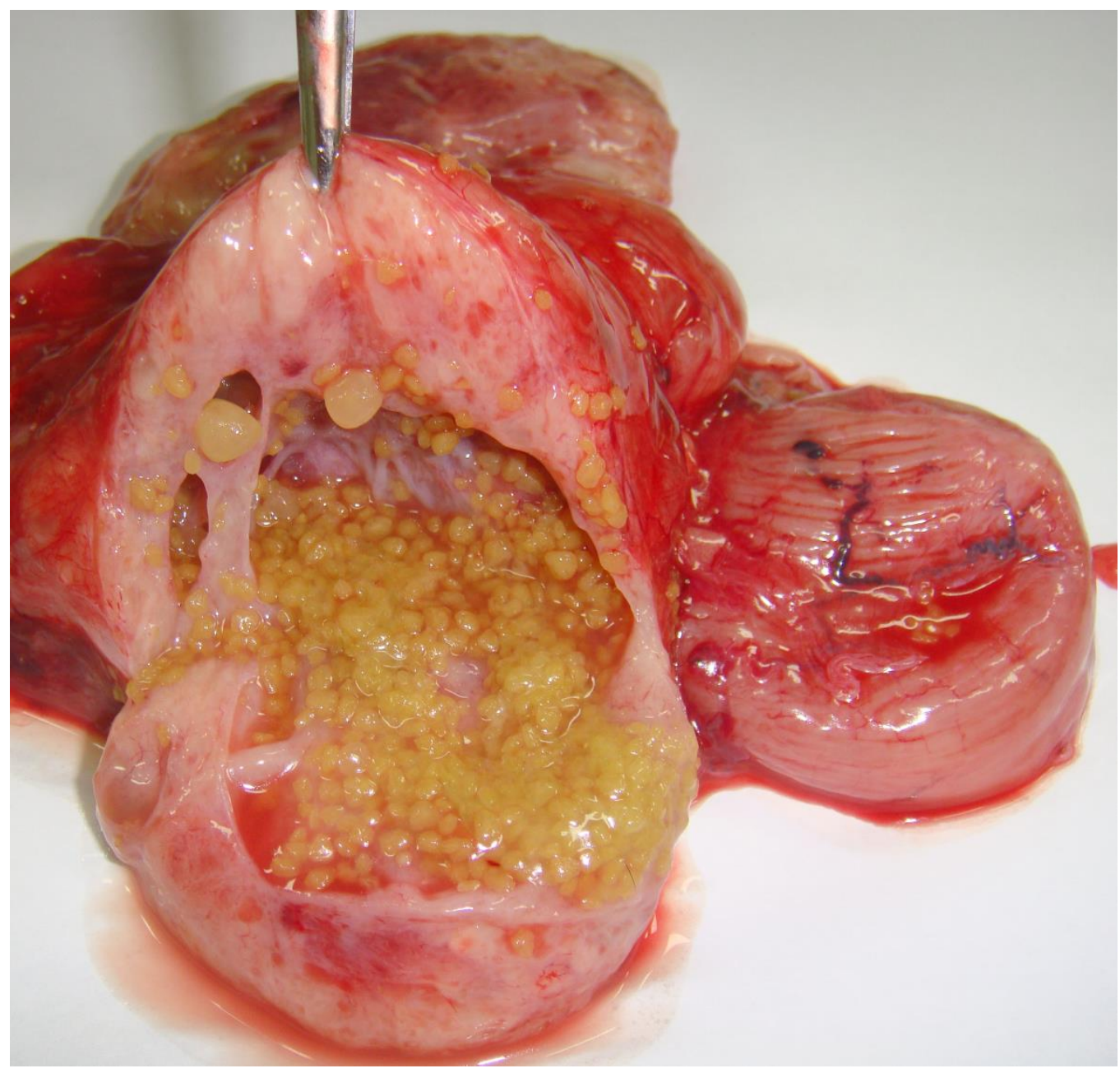

Figure 2. Endogenous prostatic calculi inside the cavitations. 


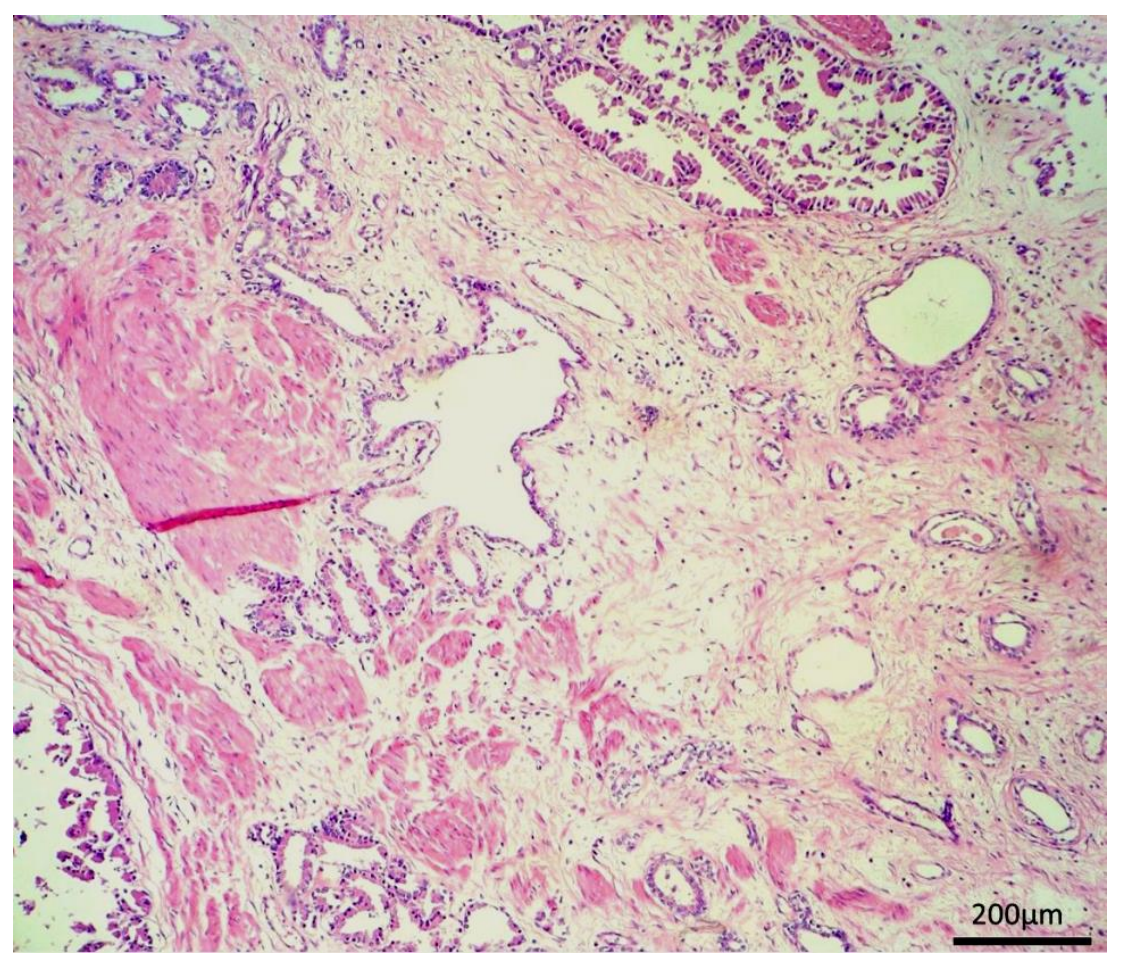

Figure 3: Histopathological photomicrograph confirming the benign prostatic hyperplasia (Staining: HE). 